\title{
The Missing Link: How Lack of Branding can drive to Failures in E-Business and E-Commerce Ventures
}

\author{
http://dx.doi.org/10.3991/ijac.v7i2.3902 \\ Adamantios Koumpis \\ National University of Ireland, Galway, IRELAND
}

\begin{abstract}
In the paper we present first hand and personal experiences from the lack of branding and how much it can influence the failure of a project or a venture. We do so in terms of present a personal failure story, namely this of the PACE toolkit, a methodology that the author has codeveloped at ALTEC Research Programmes Division for valuating intellectual and intangible assets, in parallel with the success story of the business model canvas developed by Alex Osterwalder. We emphasise on the need for e-business and e-commerce professionals and practitioners to more seriously and enthusiastically invest in branding related activities. Involving others such as future potential users or customers as well as investors is a key in the adoption and uptake of our offerings.
\end{abstract}

Index Terms-branding, e-business projects, e-commerce projects, ventures, business model canvas, valuation, value co-creation.

\section{ORGANISATIONAL BACKGROUND}

The case we present is not about a company but about a methodology we developed as part of the activities that were undertaken as part of the Research Programmes Division that the author was heading at ALTEC Software S.A. in Greece. ALTEC Software is one of the biggest ERP vendors in Greece, with activities on software, system integration (since 1st of August 2009 forming a second separate and independent subsidiary of ALTEC, namely ALTEC Integration S.A.), services and products and telecommunications, in several branches all over Greece, while also operating a subsidiary company in Romania and with a business expanding in Bulgaria, Serbia and Cyprus. ALTEC develops and provides technologically advanced systems and software applications to cover the entire spectrum of computerised and organisational demands in both the public and the private sector. ALTEC Software S.A currently has an installed base of over 50.000 companies from all business sectors in Greece.

Since its foundation in 1996, the Research Programmes Division of ALTEC Software has succeeded in opening up a set of novel research fields many of which were successfully adopted by the corporate business development and commercial departments. It has participated in a number of European and national research projects using their results for improvement of current products as also development of new innovative software products and services that cover needs of the European mark.

The Research Programme Division has fostered innovations by collaborating with academic institutions and re- search centres throughout Europe. Great emphasis is also given to internal (within the ALTEC group) technology uptake for support of existing product and service lines, which mainly address the market of ERP systems. ALTEC has a thorough experience in project management and co-ordination at the European level especially in the successful marker validation and deployment of services in Europe.

Despite the blue sky picture we give above, the subject of our case is related with a ... failure. However, it is not a case of a corporate failure - quite the opposite the author presents the case as a personal failure to make the appropriate moves that would have possibly driven us to a success story. However, our point of view is positive and optimistic: success needs failures - Samuel Beckett has stated in his Worstward Ho novella 'Try Again. Fail again. Fail better.'

\section{Setting the Stage}

Currently almost all people I know in the area of European research projects talk about the business model canvas, use the business model canvas and exchange ideas and arguments about the business model canvas. These people are researchers and academics, some of them also work in the industry. They do so in order to address a need that is apparent in all European Commission funded projects to prepare for some commercialisation, exploitation, business planning or sustainability related activities.

People see in the business model canvas an easier way to come up with things that in the past were closer to an accounting exercise - the business model canvas now seems to offer them with a postmodern, Post-it era facility they can feed with any thoughts or ideas under any of the 9 available slots. From the original canvas, there are now several differentiations and variations that can accommodate any particular need or (even worse) any style-dictated necessity. Below you can see a quite consistent application of the canvas for use in such a case of a research project, namely the BlogForEver project, for reasons that I shall describe later in this article.

Some bits of history on the canvas may be useful to the reader: Axel Osterwalder published his now best-selling book on business model generation by 2010 [1]. For sure, time has passed since some ideas that were still work in progress back in 2002 [2] converged to his $\mathrm{PhD}$ thesis [3].

In the amazon.com reviews section, the aforementioned book attracted 271 reviews of which 194 assigned to the book 5 stars while only 5 reviews gave to it only 1 star. From these 5 reviews, 3 were referred to the low quality 
of the e-book namely the kindle edition, thus leaving only 2 truly negative reviews that related to the content of the book [11].

More specifically, according to the first reviewer (Not Camping, Asheville), who claims that 'this will be my first return of a book I bought on Amazon. I really don't understand all the 4 and 5 star reviews this has received'. The reviewer states that '[...] What I expected was an easy read to help map out ideas that I have for small businesses.

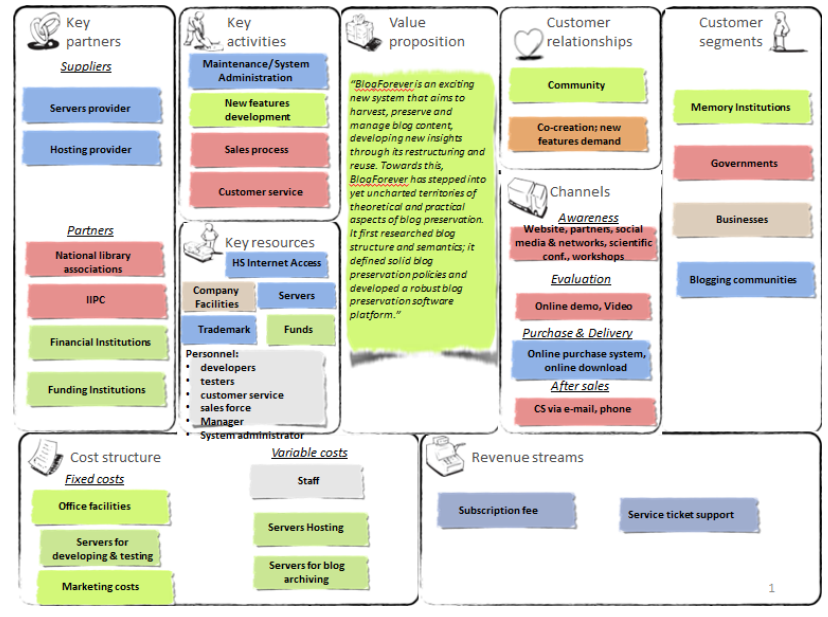

Figure 1. The BlogForever business model: an overview of the European research project BlogForever business model canvas which illustrates all nine building blocks together (source: Deliverable 6.4 Blog-

Forever Business Model, http://blogforever.eu/ )

What I got was a book full of fancy drawings surrounding some hard to read, overly-complicated text. It reads like snippets from a bad college textbook. Maybe I'm simple minded, but I appreciate plain language.'

The second reviewer was attacking the book elsewhere, and namely in the field of practice. According to him/her it is a 'nice book... very simple and easy to understand. Have you ever try to use it in practice? This knowledge is useless because it doesn 't work in real work! Nice design and easy methodology is not the purpose of the book. The Business Book must give you the power to create something new and become reach. [sic] This book is the entertainment, not the knowledge.'

I had been introduced to [1] soon after it was published. At that time I was impressed by the design of the book having read numerous other books dealing with the design of your business and business planning and all the related paraphernalia that appear in the bookshelf of an MBA student, Osterwalder's book brought a fresh air in the area.

The bottomline is that these two reviewers aren't at all wrong; it may be simply the case that they didn't let themselves fall easy victims of the viral fall-in-love symptoms of a big mass amongst whom I would include myself. Or that they weren't inclined to see value where lots of others may have seen...

\section{A. You can observe a lot by watching}

The title in the subheading above is not mine - it is one of the Yogi Berra quotes and the title in one of his books [10]. Osterwalder did either consciously, purposefully and deliberately design what happened next, or was lucky enough to enjoy it without his own involvement. I am aware that many of us like to be recognised and not have contributed or machinated our own rise in regard to recognition, reputation and image. What Osterwalder seems to have experienced is related to branding: his business model canvas succeeded in getting out of obscurity it is not by chance that he mentions all the names of the 470 co-creators of the canvas model in the book - because of an extensively well-thought and optimally executed branding exercise.

I am praising Osterwalder and his approach because I have developed or co-developed some similar frameworks and methodologies that never managed to exhibit any successful uptake and adoption - they remained in the twilight zone of made-up success which, by the time I ended investing any additional resources to them quickly made the transition to oblivion. I used the term twilight above deliberately and in a rather negative way: twilight as we know from physics is the illumination that is produced by sunlight scattering in the higher parts of the atmosphere, illuminating the lower parts of the atmosphere when the sun itself is not directly visible, so that the surface of the earth is neither completely lit nor completely dark. Same also with some of my past work that gave some 'promising' signs of a possible wider adoption and uptake though this was only an illusion and nothing would happen at all as soon as I would cease pouring any energy and efforts there. This brings us to the main postulate of this article: even if a brand has been conceived, designed and promoted by a single person, it has to be adopted and embedded by an increasingly large group of people out there so that it has a chance to set a trend, become viral and have the capacity to influence the market. And it is only by that time that one can start using the term brand for it. Any time before this happens we can talk about a brand-to-be, or a potential new brand, or anything else other than a brand. And it is this branding exercise that is currently missing in many e-business and e-commerce projects or productions that I elaborate in the following paragraphs.

\section{B. Branding needs altruism and longshot mentality}

Same as with SWOT analysis that is taught to several levels of education all over the globe but few people care to know that this method was not always with us but developed by Albert S. Humphrey, our children and grandchildren may get taught in school about the business model canvas but without any reference to Osterwalder. This way Osterwalder will have managed to establish a new brand name that will outlive him. Also he may not be able to cash in financially or in monetary terms the positive externalities that he has created with what one may call the business model canvas economy. Some easy to understand way in the form of examples of figurative meaning follow below:

People teach classes and give lectures for which they get paid using as content the canvas - is Osterwalder getting any single penny (or Euro cent) out of them? The answer is rather not...

People use the canvas to fulfil contractual obligations as part of e.g. financially supported from national or transnational agencies (like the European Commission in the above mentioned BlogForEver project) with the use of canvas as a methodology or tool to carry out their work assignments. Is, again, Osterwalder getting any money for this? No... And I am sure that many consultants make intensive use of the canvas as part of the professional ser- 
vices they provide to their customers. And again Osterwalder is not cashing any single penny.

However, Osterwalder created a brand and is given the opportunity to grasp its fruits. He may possibly fail to do so, or others may do this in a better way. Establishing a brand does not necessarily or automatically imply that you will be successful in making money out of it. But there are two thinking errors that many of us make: first that branding is an easier, more straightforward process where you can solitarily pour energy and get results out of it; second that successful branding helps you make money. For the scope of this article we limit our attention to the first and try to see the lacks and inefficiencies in many of the attempts that people make in establishing their work and being able to successfully exploit on it in commercial terms.

\section{VISITING A CASE}

\section{A. In theory there is no difference between theory and practice. In practice there is}

The title in the subheading above is attributed to Yogi Berra though it has been attributed to several others amongst them Jan van de Snepscheut (a computer scientist and educator), Manfred Eigen, and ... Karl Marx. And while for tango it takes two, for a successful branding operation you need many committed enthusiastic people, working in teams or separately, with loose or tight control, and the idea of burning scarce resources (money, working hours, sleepless nights, off-home travels) to give substance to something that may or may not succeed and which may take long time till you get the feeling whether you betted on the wrong horse or not.

Quite paradoxically, and in times where we want to think that success is some type of a promissory note, same as it is the case with banknotes that are immediately payable to bearer on demand, it may take some time till success comes: in (Finkelstein, 2000) the case of Iridium, a rather notorious venture in the area of telecommunications is presented. Its - then - CEO Edward Staiano had 'as late as 1998 [...] predicted Iridium would have 500,000 subscribers by the end of 1999'. Unfortunately, by April 1999, Iridium had only 10,000 customers and its CEO, Edward Staiano, resigned under pressure. However, and with a delay of almost twelve years, as of December 2011 Iridium had managed to achieve a base of approximately 523,000 subscribers [4].

Osterwalder may have been luckier to this, but as it seems he has rather engineered this success to happen while for Iridium they have rather ignored many of the common sense rules that should have been followed and a mentality of arrogance and too big to fail may have driven towards the initial failure, amongst other factors, of course, several of which are covered in [5].

A great part of e-commerce and e-business projects, productions (in the sense we use the term in the entertainment business area) and ventures builds on an ephemeral basis; a fast economy where people come up with a cool idea and soon after they make the launch of a Web portal or an App, they start collecting checks with five, six or seven digits by investors and financiers and thousands of downloads by customers and users. This has been an idiotic curse and a delusionary fantasy that is haunting many people's minds till today, and some of the blame is to be attributed to MBA classes where people are educated about the successes of others to only face their own individual failures tomorrow.

The role of branding is essential and can be regarded as a seamless parallel process that continuously feeds the particular venture with positive only input, spanning from immaterial assets like reputation, goodwill, image, recognition, visibility, word of mouth and emotions. In this respect, branding helps the core process of value creation which will not depend on the particular technology or any other feature(s) used for the implementation of the project.

Of course the choice of a 'wrong' technology or the association with the 'wrong' features can facilitate a failure. Same important is the choice of the users: imagine a Tweeter that might have been invented or conceived for messages in some neo-nazi group or for the members of some extremist group? Nobody should be making any second thoughts about the poor uptake and business potential of such an, otherwise, promising technology. On the other hand it is easy to disassociate an e-business / ecommerce offering from a wrong context and re-position it to a new one. This continuous give and take of feedback between the market(s) and the core project team is what branding is at the end; you get messages from the market, you interpret and process them and you reposition your offering. Quite not rocket science at all - but who said that it takes a lot to fail in the small things?

\section{$B$. The case of PACE: failing without a failure}

In the past when I was with my previous position heading the Research Programmes Division of ALTEC (http://research.altec.gr), we had for a rather short period of time been involved in many research projects concurrently. This is not the usual case for academic or research institutions where you have people fully assigned in a single project and in some few cases also in two. Being able to watch the inner processes in several projects, and having (at some time at least) very good and genuinely good communications amongst us (something that I regret to say rarely happens in institutions that concentrate a high number of intelligent individuals who have never learned to work together in teams and are continuously caring about themselves only) we created capacities and skills that would be rarely found in the market. At some point we came to the idea that we could transfer parts of this know how into a methodology that would help research consortiae make better use of the intangible assets and the intellectual capital they were creating so that exploitation and commercialisation of the project outcomes could take place easier or at all. I should note here that for European research projects there is a long tradition of doing very few things regarding this part and so we thought that anything we do would be in the right direction and easily liked and loved. We were a little bit naïve as the story will show.

We developed PACE - a methodology for valuating Project Assets, Core competences and Exploitable items [6], [7]. The methodology was based on an approach developed by Donald Andriessen [8]. His book we loved and had passionately read and discussed many times. One of the team members has also decided later to have his PhD in a nearby area. We started passionately talking about PACE in the projects we were involved and people were always listening with interest. All the initial feedback we got was very positive. Momentum seemed to be gained. And then things started going backwards: people were 
happy to hear about PACE but didn't find it easy to use it. At that point we saw an opportunity of organising PACE workshops and also bilateral sessions to help them make use of it. But again things were not promising at all. And then silently we made some publications and used this in some offers as an accessoire - not very relevant perhaps but not bad to include amongst other more relevant tools and methods. So we felt that PACE would be dying soon and we preferred to bury it or choose some type of zombie state for its later existence.

\section{Current Challenges/Problems Facing the ORGANIZATION}

The reasons for failure are many - and while people say that "success has many fathers, failure is an orphan" I never thought to shift responsibility for the PACE failure to anyone else than myself. The problem I was facing was: what did I do wrong? What did go wrong? Which mistakes have I made? Which were the wrong assumptions I made? Perhaps the market was not ready yet to accept something like this; perhaps I was trying to push it for adoption to the wrong people; perhaps I was using too complicated terminology (though I personally felt that I had oversimplified Andriessen); perhaps the way we were 'teaching' people was not good. And a lot of other reasons came to my mind. Can you now imagine the case of Osterwalder - hypothetically now, of course - asking himself the same questions in case the canvas wouldn't have succeeded?

Now that I look back I think that I made all the right questions to myself. The problem was that I wasn't doing anything to deal with the 'possible' mistakes. I haven't changed my market and the people I was selling it to; and I didn't do anything to change the terminology - or making the steps easier to use (something that Osterwalder does with the canvas: one can fill out all nine segments of the canvas while we were sticking to some non-value creating sequential approach used in algorithms in the old programming world paradigm of structured programming but not what people do in business...). And also the way that we were teaching people was totally uncool - something like sex lessons organised by the Catholic church or even worse. Good for intellectuals but too bad for consumers. If you read again the two negative reviews for Osterwalder mentioned in the introduction, you shall see that they both admit that the book was well designed and was 'nice'. I have to confess that this was the first thing that attracted me to the book. So if the first impression your stuff makes to others is not excessively positive, everything starts to get difficult.

We were not as unsuccessful at all, one can say. We envisioned PACE and had it 'realised' for some time. It is only that we failed in making a bigger 'viral' success and keeping it alive as a methodology or a resource used intensively by a community. What we failed to see - same as many other e-business and e-commerce practitioners is that our job is not only to develop the technology or the tools but also carry out successfully the branding part as well.

Actually what we were trying to develop in some way was some type of the business model canvas combined together with a canvas with valuation capabilities - something that a bit later on Osterwalder came up with the Business Model Toolbox which was promoted for combining 'the speed of a napkin sketch with the smarts of a spreadsheet' and which is now provided as an App (http://www.businessmodelgeneration.com/toolbox/bmtbo x).

One might see that having been so close to a potential success I may personally have feelings of bitterness envying the victory of canvas over PACE. Quite not: from the first moment it was easy for me to see that there was something wrong and something missing, namely the branding part, in our approach, though at that stage I was not able to recognise it exactly. This is not the right place for speculations - it may be that my first degree and all my background were in Computer Science while Osterwalder had an education in Political Science and Management. For a computer scientist a revolution starts when you write (or compile ...) a piece of software code while for a political scientist it is cliché knowledge that revolutions start out in the streets and it is good for an engineered revolution to have your followers supplied with well-prepared and easy-to-function and operate Molotov cocktails. And the canvas was that type of an easy to spread and disseminate intellectual artefact that could relatively easy become the subject of wider adoption and uptake. I shall speak for myself: Osterwalder made perhaps the most important contribution in the business community after 2000 . The sooner we shall recognise it the better for all of us. And he did so by means of an exceptionally successful branding that involved 470 co-authors all of whom are listed in the beginning of the book and some of them that I met personally feel proud of having been a contributor or a co-author to the book.

Even if the book may not be worth for some people as the two reviewers mentioned in the beginning of the article, it is worth for you to read the process as this is presented in page 275 of [1].

'The core team, consisting of Alexander, Yves, and Patrick start the project with a number of meetings to sketch out the business model of the book. The Hub is launched to co-create the book with business model innovation practitioners throughout the world. Creative Director Alan Smith of The Movement hears about the project and puts his company behind it. Finally, Hub member Tim Clark joins the core team after recognizing the need for an editor. The group is completed by JAM, a company that uses visual thinking to solve business problems. An engagement cycle is started to pump fresh "chunks" of content out to the Hub community for feedback and contributions. The writing of the book becomes completely transparent. Content, design, illustrations, and structure are constantly shared and thoroughly commented upon by Hub members worldwide. The core team responds to every comment and integrates the feedback back into the book and design. A "soft launch" of the book is organized in Amsterdam, Netherlands, so members of the Hub can meet in person and share their experiences with business model innovation. Sketching out participant business models with JAM becomes the core exercise of the day. Two hundred special limited edition prototypes of the (unfinished) book go to print and a video of the writing process is produced by Fisheye Media. After several more iterations the first print run is produced.'

Same important are some numbers that are given to document the background process for this - I copy them from the same source and would like to put them next to what we did with PACE: 
TABLE I.

COMPARISON OF NUMBERS OF INTERACTIONS AND QUANTITATIVE ESTIMATES FOR THE BUSINESS MODEL CANVAS AND THE PACE TOOLKIT.

\begin{tabular}{|c|c|}
\hline $\begin{array}{l}\text { Canvas - numbers as } \\
\text { presented in the book: }\end{array}$ & PACE - rough estimates: \\
\hline $\begin{array}{l}9 \text { years of research and practice } \\
470 \text { co-authors } \\
19 \text { book chunks } \\
8 \text { prototypes } \\
200 \text { copies of a messed up test print } \\
77 \text { forum discussions } \\
287 \text { Skype calls } \\
1,360 \text { comments } \\
45 \text { countries } \\
137,757 \text { views of method } \\
\text { online before book publishing } \\
13.18 \text { GB of content } \\
28,456 \text { Post-it } \\
4,000+\text { hours of notes used } \\
521 \text { photos }\end{array}$ & $\begin{array}{l}4 \text { years of research - low to no practice } \\
2 \text { main authors and } 5 \text { other lukewarm contributors } \\
4 \text { papers and } 1 \text { (badly written) 'manual' } \\
1 \text { prototype } \\
\text { None } \\
\text { ca. } 10 \text { small group / core team (: } 2 \text { persons) discussions } \\
\text { less than } 10 \\
\text { less than } 10 \text { or } 20 \\
1 \text { country } \\
\text { Less than } 100 \\
\text { online access } \\
\text { few megabytes } \\
\text { hmm... } \\
\text { ca. } 250-300 \text { hours } \\
\text { not even a single photo from all events we organised! }\end{array}$ \\
\hline
\end{tabular}

\section{EPILOGUE AND LESSONS LEARNED}

Branding is a mainly communication function. Molly Hislop writes that 'a simple way to measure the effectiveness of advertising, as stated by the head of online advertising at a large packaged goods company is to "stop advertising and see what happens"' [9]. In this respect, by the time we stopped doing anything about PACE nothing happened except some anaemic and sporadic citations we still receive from postgraduate students burning the midnight oil for their bibliography desk research trying to find who else may have published something same strange or bizarre. On the other hand, all may agree that the canvas has a life to live and some more miles to go even if the core team retired and stopped doing anything new to support it.

Hislop in [9] defines branding as 'the process of creating an association between a symbol / object / emotion / perception and a product / company with the goal of driving loyalty and creating differentiation'. In order to see your e-business or e-commerce project, production or venture succeed in having a critical mass of followers and achieve an installed base you have to continuously and uninterruptedly invest in building relationships and connection between your offering and the people out there. One could add next to the 'Osterwalder' metrics some other non-conventional ones which I truly believe: how many coffees (espressos, lattes, Americanos, macchiatos, etc.) have you had with people talking to them and holding value-creating conversations? How many bottles of wines have you enjoyed or consumed with your extended team members and future value co-creators for your ideas? How many small- or micro-projects or events or ventures have you established and sponsored next to your mega-project or production to allow for other people to position themselves and create a mutually beneficial space for them? Otherwise why care find 470 fool people to follow you unless they don't see that they also get some value out of it? You might not even find 4 at all.

This article wouldn't be complete if I left out an important thinking error I personally made on branding. This has to do with my own conceptualisation about the 'shadow' linkage between branding and viral marketing. For the latter the general understanding is that it aims to cre- ate a strong appeal to people with high social networking potential and produce increases in brand awareness which can help achieve any particular marketing objectives through self-replicating 'viral' processes, be them word of mouth or any other activity that can create a multiplicative snowball effect and all this within a short period of time. I am afraid that the mistake I and many other people do is that this type of viral uptake was not holding even in the ancient pre-Internet and pre-Tweeter times. In fact, Paul the Apostle whose influence on Christian thinking arguably has been more significant than any other and is generally considered as one of the most important figures of the Apostolic Age for Christianity and what it is today, has understood and it is therefore that he foresaw the need to start churches in his lifetime. And it is this element that Osterwalder did in terms of establishing a community of 470 co-authors. If you want to find willing customers, partners, investors and users you have to 'plant churches' close to them - in our times this doesn't need to be physically or geographically close but it does need to be contextually close to their needs, their interests and their motivations.

\section{REFERENCES}

[1] Osterwalder A., Pigneur Y., Smith A. (2010) Business Model Generation, Wiley

[2] Osterwalder A. and Pigneur Y. (2002) An e-Business Model Ontology for Modeling e-Business, in the 15th Bled Electronic Commerce Conference 'e-Reality: Constructing the e-Economy', Bled, Slovenia, June 17 - 19, 2002

[3] Osterwalder A. (2004) The Business Model Ontology - A Proposition In A Design Science Approach, PhD thesis, University of Lausanne

[4] Wikipedia (2013) Iridium Communications Present status. Retrieved May 19 2014, from http://en.wikipedia.org/wiki/Iridium Communications\#Present status

[5] Finkelstein S. and Sanford S. H. (2000) Learning from Corporate Mistakes: The Rise and Fall of Iridium, Organizational Dynamics, 29 (2):138-148 http://dx.doi.org/10.1016/S0090-2616(00)00020-6

[6] Koumpis A., Christofilopoulos E., Melanitis N. (2005) And after the RTD project what? Some experiences and ideas on the exploitation of RTD projects results, e-challenges 2005 Conference, 19 21 October 2005, Ljubljana, Slovenia

[7] Koumpis A., Mavridis A. (2006) The PACE Exploitation toolkit, eChallenges 2006 Conference, 25 - 27 October 2006, Barcelona, Spain

[8] Andriessen D. (2004) Making Sense of Intellectual Capital: Designing a method for the valuation of Intangibles, Butterworth Heinemann, 2004

[9] Hislop M. (2001) Branding 101: An overview of branding and brand measurement for online marketers, Dynamic Logic Report, April 2001

[10] Berra Y. (2009) You can observe a lot by watching, Wiley, 2009

[11] Amazon (2014) http://www.amazon.com/Business-ModelGeneration-Visionaries-Challengers/product-reviews/0470876417/ $\underline{\mathrm{ref}=\mathrm{cm} \text { cr } \mathrm{dp} \text { qt hist one } \mathrm{ie}=\mathrm{UTF} 8 \& \text { filterBy }=\text { addOneStar\&sho }}$ wViewpoints $=0$, accessed May 192014

\section{AUTHOR}

Adamantios Koumpis is Research Fellow at the Digital Enterprise Research Institute of the National University of Ireland, Galway (adamantios.koumpis@deri.org).

Submitted 22 May 2014. Published as re-submitted by the authors on 08 June 2014. 